such a self-styled body. We have no observations to make upon the objects and activities of the two bodies of this type referred to above, but scientific workers must themselves decide whether either a "Faculty" or "College", constituted as we have stated, merits their support.

\section{Major E. E. Austen}

Major E. E. Austen retired from the keepership of the Department of Entomology in the British Museum (Natural History) on October 19, when he reached the age limit of sixty-five years. After an education at Rugby School and the University of Heidelberg, he entered the service of the Trustees of the British Muscum as second class assistant (now termed assistant keeper) in what was then the entomological section of the Department of Zoology on October 30,1899, and was placed in charge of the Diptera; to this group of insects he has dovoted his scientific life. The entomological section was soparated from the Department of Zoology in 1913 with Dr. C.J. Gahan as the first keeper; on his rotirement, Major Austen succeeded to the office on January 21, 1927. His last official act was to bring out the long wanted number on Clothes Moths and House Moths in the Natural History Museum economic series. As the blood-sucking flies are in the group studied by him, he has been brought closely into contact with tropical medicine. Ho was with the first expedition of the Liverpool School of Tropical Medicine to Sierra Leono in 1899, and has been a member of the council as well as vice-president of the Royal Society of Tropical Medicine and Hygiene. He has served on many committees including those on sleeping sickness, tsetse fly, and locust. $\mathrm{He}$ is a member of the committeo of management of the Imperial Institute of Entomology. In early days a volunteer and later a territorial, he saw service in the Boor War and in the European War; in the latter he was twice mentioned in dispatches and was awarded the Distinguished Service Order. Mr. N. D. Riley succeeds Major Austen as keeper, and Mr. K. G. Blair has been appointed deputy keeper in the Department of Entomology of the Museum.

\section{The Asiatic Society of Bengal}

Although scientific workers in many fields are familiar with the publications of the Asiatic Society of Bengal, few, probably, are aware of the mass influence of this ancient foundation upon Indian progress. A glimpse of the long history of the Society was given by Dr. Rai Upendra Nath Brahmachari, in his presidential address in 1929 , just published in the Journal and Proceedings (N.S., vol. 25, 1932). Founded in 1784, as the result of an appeal by Sir William Jones for the institution of a society to inquire into the history, civil and natural, the antiquities, arts, sciences and literature of Asia, and numbering amongst its early patrons Warren Hastings and Lord Cornwallis, the Asiatic Society set going inquirics of a kind which had fallen into abeyance in the India of the late eighteenth century. Its "Asiatic Researches" created so great an impression in the literary world that in 1798 a pirated edition was brought out in England, and on the Continent a French edition, "Recherches Asiatiquos", appeared in Paris. So early as 1808, a year after the formation of the Geological Society of London and only eighteen years after Werner had propounded at Freiburg his doctrine of "Formations", a special committee was formed "to propose such plans and carry on such correspondence as might seem best suited to promote the Natural History, Philosophy, Medicine, improvements of the Arts and Sciences and whatever is comprehended in the general term Physics".

AT first geology and mineralogy recoived most attention, and the names of many distinguished workers figure amongst the early contributorsVoysey the father of Indian geology, Oldham who created the Geological Survey of India, Lambton of the Indian Survoy, Schwendler one of the chief founders of the Calcutta Zoological Gardens, Falconer, Cautley, Colvin, Baker, Durand, to mention a few. Indeed there are few activities in the scientific life of India which have not been linked with the Asiatio Society, from the early othnological survey of Col. Dalton, and the grand series of papers on the fossil mammalian fauna of the Sub-Himalayas, to the foundation of the Indian Museum and its off-shoot the Zoological Survey. The president added a note of warning about the risk of starting now scientific periodicals, the competition of which might result in the double misfortune of loss both to the new and the old, and made a plea for consideration of the possibility of concentrating upon the oldest journal of all, the Journal of the Asiatic Society of Bengal, with which, he considers, many of the new journals might be amalgamated profitably.

\section{Ultra-Short Wave Radio Link across Bristol Channel}

ONE of the results of the study of the mode of propagation of ultra-short electric waves has been to show that for wave-lengths of from one to about nine metres, the effective range is limited to the horizon or the optical distance for ordinary vision. While this property prevents the application of such waves for long distance radio communication, it has for some timo been rocognised that this range of wave-lengths would be very suitable for providing a radio link in the ordinary telephone system. This application is of particular advantage in spanning short stretches of water, such as a channel or river estuary, where the prosont alternative is a submarine cable or a land-line following a circuitous route. According to recent reports in the Times and the Wireless World, the Post Office Engineering Dopartment has been investigating tho possibilities of this application for some time past, and exporiments have now successfully terminated in the setting-up of a radio link across the Bristol Channel. This link, which is twelve miles long, connects up the ordinary tolophone land-lines at Lavernock, near Cardiff, on one side, with those at Hutton, near Weston-superMare, on the other. The wave-length employed is about five metres, and the transmitters and receivers are placod in separate huts at each site. The aerial

No. 3286, Vol. 130] 